\title{
„Obchody Międzynarodowego Dnia Pamięci o Ofiarach Holocaustu na Podkarpaciu - retrospekcja" - wystawa w Muzeum Uniwersytetu Rzeszowskiego
}

\section{$\mathrm{Z}$}

okazji XII Obchodów Międzynarodowego Dnia Pamięci o Ofiarach Holocaustu na Podkarpaciu Muzeum Uniwersytetu Rzeszowskiego przygotowało wystawę retrospektywną przedstawiającą historię upamiętniania tego ważnego wydarzenia. Koncepcja wystawy i projekt graficzny został przygotowany przez Martę Lasotę, we współpracy z Mateuszem Mrozem, doktorantem Instytutu Historii Uniwersytetu Rzeszowskiego, oraz przy konsultacji Kierownika Zakładu Historii i Kultury Żydów w Instytucie Historii Uniwersytetu Rzeszowskiego, dr. hab. prof. UR Wacława Wierzbieńca.

Celem wystawy, zatytułowanej „Obchody Międzynarodowego Dnia Pamięci o Ofiarach Holokaustu na Podkarpaciu - retrospekcja" było podsumowanie inicjatywy zapoczątkowanej w 2009 roku przez prof. Wacława Wierzbieńca, a także przedstawienie jej jako wydarzenia wyjątkowego w skali kraju. Z roku na rok powiększała się liczba miejscowości, które dołączały do organizowanych przez Uniwersytet Obchodów. W 2017 roku uroczystości odbyły się już w 38 miejscowościach Podkarpacia, a w 2019 roku pamięć pomordowanych Ofiar Holokaustu uczczono już w niemal 70 miastach i miasteczkach regionu. W 2019 roku partnerem wydarzeń stało się województwo lubelskie. Corocznie w organizację Międzynarodowego Dnia Pamięci o Ofiarach Holokaustu na Podkarpaciu angażuje się wiele instytucji, organizacji i osób prywatnych (między innymi władze samorządowe, Instytut Pamięci Narodowej Oddział w Rzeszowie, Kuria Diecezjalna w Rzeszowie, Fundacja Ochrony i Dziedzictwa Żydowskiego, a także szkoły, miejskie i gminne ośrodki kultury, biblioteki). Głównym celem Obchodów jest uczczenie Ofiar Holokaustu, a także pielęgnowanie pamięci o tym trudnym rozdziale naszej historii. Wydarzenie to uczy tolerancji i pomaga w nawiązywaniu pozytywnych relacji między obywatelami Polski i Izraela. Organizatorzy nie unikają tematów trudnych, które często budzą kontrowersje wśród historyków, a także Polaków i Żydów. Podczas licznych wykładów i spotkań ze świadkami tamtych wydarzeń poruszane są różne aspekty Zagłady Żydów, w tym także stosunków polsko-żydowskich. Merytoryczna dyskusja z udziałem młodzieży i członków lokalnych społeczności wpływa na poszerzenie wiedzy i świadomości o Holokauście, a także o historii Żydów w swoich małych ojczyznach. Świadczyć może o tym tak liczne zaangażowanie władz i mieszkańców wielu miejscowości Podkarpacia w uczestnictwo w Obchodach Międzynarodowego Dnia Pamięci o Ofiarach Holokaustu. Poszerzanie wiedzy na temat Żydów, ich historii i przynależności do dawnych społeczności wielu podkarpackich miast i miasteczek wpłynęło między innymi na to, że odnowiono wiele cmentarzy żydowskich. Miejsca, w których dokonywano egzekucji czy obszary dawnych gett zostały otoczone opieką i pamięcią. 
Wystawa retrospektywna, którą prezentowano w Uniwersytecie Rzeszowskim przy okazji Obchodów Dnia Pamięci, została podzielona na kilka wątków, które w pełni odzwierciedlają ich szczególny charakter. W pierwszej kolejności przedstawiono historię i przebieg Obchodów w poszczególnych latach, a także wyróżniono ważne momenty, które dodają rangi temu wydarzeniu. Zaprezentowano archiwalne dokumenty, takie jak list do prof. Wacława Wierzbieńca od Sekretarza Stanu, Pełnomocnika Prezesa Rady Ministrów do Spraw Dialogu Międzynarodowego, Władysława Bartoszewskiego. List ten został przysłany w podziękowaniu za zaproszenie na pierwsze Obchody Międzynarodowego Dnia Pamięci o Ofiarach Holokaustu na Podkarpaciu w 2009 roku. Autor podkreślał w nim, jak ważne jest pielęgnowanie pamięci o ofiarach obozów koncentracyjnych, a także nauczanie o tym trudnym rozdziale w dziejach ludzkości. W czasie drugich Obchodów w 2010 roku nadano odznaczenia państwowe Polakom ratującym Żydów podczas Zagłady. W imieniu Prezydenta Rzeczypospolitej prof. Lecha Kaczyńskiego odznaczenia wręczyła Pierwsza Dama - Maria Kaczyńska w asyście minister Ewy Jurczyk-Ziomeckiej. Wyróżnienia te nadano siedemdziesięciu zasłużonym osobom, mieszkańcom Podkarpacia. Szczególnym momentem w historii Obchodów było przyznanie w 2019 roku godności doktora honoris causa Uniwersytetu Rzeszowskiego Profesorowi Shimonowi Redlichowi. Profesor jako dziecko przeżył Zagładę Żydów w Brzeżanach, po wojnie wyemigrował do Izraela. Studiował historię na Uniwersytecie Hebrajskim, a także sowietologię na Uniwersytecie Harvarda. Shimon Redlich opublikował wiele książek i artykułów na temat historii Żydów w Związku Radzieckim, Polsce i na Ukrainie. Od lat aktywnie działa na rzecz poprawy relacji polsko-żydowskich i ukraińsko-żydowskich.

Jednym z najważniejszych wydarzeń towarzyszących Obchodom są spotkania i świadectwa wygłaszane przez Ocalonych z Holokaustu i ich potomków. Znaczna część wystawy została poświęcona przedstawieniu sylwetek osób, które będąc gośćmi Uniwersytetu Rzeszowskiego, dzieliły się ze słuchaczami swoimi przeżyciami wojennymi.

W latach 2009 i 2010 w Obchodach Dnia Pamięci uczestniczył Shlomo Wołkowicz, który - jak sam mówił - „przeżył własną śmierć”. Urodził się w 1925 roku w Jagielnicy. W czerwcu 1941 roku, po napaści III Rzeszy na Związek Radziecki, zdecydował się na ucieczkę ze Lwowa (gdzie uczęszczał do szkoły średniej) na wschód. Wraz z grupą rówieśników dotarł do Złoczowa. Tam niemal zginął podczas wyjątkowo brutalnej niemieckiej egzekucji. Żydów, których zmuszono do zbierania martwych więźniów pozostawionych przez NKWD, zaczęto rozstrzeliwać seriami z karabinu maszynowego. Wołkowicz upadł na stertę zwłok, lecz przeżył osłonięty kolejnymi zabitymi. Po tym zdarzeniu, w wyniku sprzyjających okoliczności udało mu się uzyskać dokumenty potwierdzające jego „aryjskie” pochodzenie i przeniósł się do wsi Woroniaki, skąd nawiązał kontakt z rodziną. Został rozpoznany jako Żyd przez mieszkańców wsi, co zmusiło go do powrotu do Lwowa, gdzie pracował w fabryce tytoniu i podrabiał dokumenty dla ukrywających się Żydów. Ze swoimi wojennymi traumami zmagał się przez wiele lat, by w końcu opisać je w książce Wrota piekieł, która ukazała się w języku niemieckim i polskim. Jego historia to dzieje terroru, strachu, nieoczekiwanej wrogości ze strony jednych oraz niespodziewanej pomocy innych. Zmarł 13 marca 2014 roku w Hajfie. 
Lucia Retman w Obchodach Międzynarodowego Dnia Pamięci o Ofiarach Holokaustu na Podkarpaciu uczestniczy corocznie od 2010 roku. Chętnie spotyka się z młodzieżą podkarpackich szkół i lokalnych społeczności, aby przekazywać swoje bolesne wspomnienia i przeżycia. Pomimo swoich przykrych doświadczeń, do których wraca, gdy upamiętniamy Ofiary Holokaustu, Lucia Retman emanuje ogromną pogodą ducha, ciepłem, życzliwością i przekazuje mądrość życiową, którą udało jej się przekuć z cierpienia, jakiego doświadczyła w latach swojej młodości. Urodziła się w 1928 roku w Dynowie, w rodzinie Pesi z domu Ringel i Mojżesza Grünspama. We wczesnym dzieciństwie opiekę nad Lucią powierzono siostrze jej matki - Emilii, która razem z mężem Mojżeszem mieszkała w Leżajsku. Po wybuchu wojny, w atmosferze strachu o swoje życie, Lucia wraz z wujostwem poszukiwała innego miejsca do zamieszkania. Przenieśli się do Sądowej Wiszni, a następnie do Żółkwi. Tam zmarł wuj Mojżesz, a pogarszający się stan zdrowia ciotki zmusił Lucię do opuszczenia Żółkwi i przeniesienia się do swojej siostry Miriam, która razem z mężem zamieszkała w Lubaczowie. Tam, dzięki pomocy Zofii Pomorskiej i lokalnego księdza, udało się zapewnić Luci metrykę chrztu. Dzięki temu, 26 sierpnia 1943 roku uzyskała nową tożsamość - Janina Kogut. Pod nowym nazwiskiem zgłosiła się dobrowolnie do Arbeitsamtu (biuro pracy), gdzie skierowano ją na roboty do Niemiec. W maju 1945 roku powróciła do Polski. Udało jej się odszukać szwagra i zdobyć informacje o siostrze Miriam. Dnia 19 października 1946 roku wyruszyła w podróż do Palestyny, wtedy też poznała swojego przyszłego męża Kalmana, z którym osiedliła się na stałe w Hajfie i mieszka tam do dziś. Po latach, w 2009 roku dzięki staraniom Luci Retman, Zofia Pomorska została pośmiertnie odznaczona medalem Sprawiedliwy wśród Narodów Świata.

Judith Elkin w podkarpackich Obchodach Dnia Pamięci uczestniczy od 2011 roku. Bierze udział również w odbywającym się od 17 lat Marszu Pamięci ofiar getta rzeszowskiego. Urodziła się w 1938 roku w Rzeszowie w rodzinie Haas, jej ojciec pochodził z Rogóżna, a matka - Ryfka Thurm - z Przybyszówki. Po ślubie rodzice Judith przeprowadzili się do Przeworska, w którym mieszkali do wybuchu drugiej wojny światowej. Judith razem z rodzicami trafiła do przeworskiego, a później rzeszowskiego getta, skąd dzięki pomocy trójki Polaków uciekli do Uzbekistanu. Po zakończeniu wojny Judith Elkin powróciła do Polski, ale nikt z pozostałej tutaj rodziny nie ocalał, dlatego po wielu staraniach wraz z rodzicami przeprowadziła się do Izraela. Tam Judith poznała swojego męża, z którym wyemigrowała do USA, by osiedlić się tam na stałe.

Kilkakrotnie w Obchodach Międzynarodowego Dnia Pamięci o Ofiarach Holokaustu na Podkarpaciu uczestniczyła Anna Rzeszowska. Urodziła się 21 lutego 1944 roku w Warszawie. Jej rodzice - Helena z domu Toper i Herman Tannenbaum poznali się w Rzeszowie, gdzie wzięli ślub w 1941 roku. Niedługo później opuścili Rzeszów, aby przenieść się do Warszawy. Tam rodzina Heleny, Hermana i Anny Tannenbaumów dzięki pomocy Zdzisława Kulpy ukrywała się po stronie aryjskiej do zakończenia wojny. Anna Rzeszowska jest prawnuczką rzeszowskiego filantropa - Adolfa Tannenbauma, który przed II wojną światową ufundował między innymi Żydowski Dom Ludowy w Rzeszowie. W budynku tym znajdowało się Żydowskie Liceum, bogato wyposażona biblioteka, a także swoje spektakle prezentowało Towarzystwo Dramatyczne „Scena”. Dzisiaj w budynku tym mieści 
się Wojewódzki Dom Kultury, który swoją misją i ofertą edukacyjną kontynuuje dzieło Adolfa Tannenbauma. W ostatnich latach w Obchodach uczestniczy również wnuczka Anny, Izabella Rzeszowska, która na co dzień jest aktorką Teatru Żydowskiego w Warszawie.

Ostatnią z wyróżnionych na wystawie postaci jest Shimon Redlich, który gościł w Uniwersytecie podczas kilku Obchodów Dnia Pamięci. Profesor Redlich jest cenionym historykiem, autorem wielu publikacji dotyczących losów społeczności żydowskiej w ZSRR, Polsce czy na Ukrainie. Urodzony we Lwowie w 1935 roku, dzieciństwo przeżył w Brzeżanach, gdzie dzięki pomocy rodziny polskiej i ukraińskiej udało mu się przetrwać Zagładę. Stanisław i Karol Codogni pomogli w ucieczce z getta Shimonowi i jego matce, a następnie zorganizowali im schronienie w pobliskiej miejscowości Raj. Po latach, w roku 1983, profesor Redlich - najmłodszy z ukrywanych Żydów - podziękował Karolowi Codogniemu, który wkrótce został odznaczony medalem Sprawiedliwy wśród Narodów Świata. Po wojnie Shimon Redlich wyemigrował do Izraela, wcześniej jednak wystąpił w ostatnim zrealizowanym w Polsce filmie w języku jidysz - Nasze dzieci Natana Grossa. Obraz prezentował wojenne przeżycia wychowanków sierocińca dla dzieci żydowskich w Helenówku pod Łodzią. 28 stycznia 2019 roku podczas XI Obchodów Międzynarodowego Dnia Pamięci o Ofiarach Holokaustu na Podkarpaciu odbyła się ceremonia nadania prof. Redlichowi tytułu doktora honoris causa Uniwersytetu Rzeszowskiego.

W dalszej części wystawy zaprezentowano inne inicjatywy upamiętniające Ofiary Holokaustu na Podkarpaciu, jakie podejmowano w Uniwersytecie Rzeszowskim. W 2016 roku uczniowie Dwujęzycznego Liceum Uniwersyteckiego w Rzeszowie wzięli udział w projekcie edukacyjnym „Szkoła Dialogu”. Celem programu było poznanie historii i kultury Żydów w swoim miejscu zamieszkania. Uczniowie samodzielnie odkrywali historię żydowskiej społeczności Rzeszowa, odwiedzali miejsca szczególnie z nią związane, a także poznali sylwetki Żydów zasłużonych i zaangażowanych w rozwój dawnego Rzeszowa. Efektem końcowym było przygotowanie spaceru śladami rzeszowskich Żydów, podczas którego uczniowie wcielili się w rolę przewodników. Ostatnim punktem programu było odtworzenie wieczoru szabasowego, połączonego z degustacją specjałów kuchni żydowskiej przygotowanych samodzielnie przez uczniów DLU.

Od 3 maja 2016 roku podczas rzeszowskiego Święta Paniagi odbywa się spacer po miejscach związanych z dawną żydowską społecznością Rzeszowa. Uczestnicy są zapoznawani z historią rzeszowskich Żydów, a także oprowadzani po miejscach szczególnych: placu pocmentarnym, miejscach modlitwy, budynkach użyteczności publicznej. W 2017 roku spacer został zakończony recitalem Izabelli Rzeszowskiej, która wystąpiła na scenie dawnego Żydowskiego Domu Ludowego, ufundowanego w 1928 roku przez jej przodka - Adolfa Tannenbauma. W maju 2019 roku spacer zakończył się w budynku dawanej Synagogi Nowomiejskiej (dzisiejsze Biuro Wystaw Artystycznych), gdzie odtworzono film Powroty Szymona, opowiadający losy prof. Shimona Redlicha. Projekcję filmu uzupełniła wystawa autorstwa Muzeum Okręgowego w Rzeszowie pod tytułem „Ślady przeszłości - fotografie Żydów rzeszowskich z końca XIX i początków XX wieku”. Przewodnikami podczas spaceru są Marta Lasota i Mateusz Mróz (we wcześniejszych latach także Ewa Trojanowska i Katarzyna Gudzik). 
W latach 2016-2017 Zakład Historii i Kultury Żydów w Instytucie Historii Uniwersytetu Rzeszowskiego we współpracy z Małką Shacham-Doron z Izraela zorganizował dwie edycje Warsztatów Kultury Izraelskiej. Ich uczestnicy mieli możliwość nauczenia się podstaw języka hebrajskiego, historii i kultury Izraela, a także poznania różnych zwyczajów i obrzędów praktykowanych podczas świat żydowskich. Warsztaty te były skierowane nie tylko do społeczności akademickiej Uniwersytetu Rzeszowskiego, ale także do wszystkich mieszkańców Rzeszowa i Podkarpacia.

Wystawa „Obchody Międzynarodowego Dnia Pamięci o Ofiarach Holokaustu na Podkarpaciu - retrospekcja” miała na celu podsumowanie dotychczasowej, dwunastoletniej historii tego wydarzenia organizowanego przez Uniwersytet Rzeszowski. Dnia 19 lutego 2020 roku została zaprezentowana Ambasadorowi Izraela w Polsce, Aleksandrowi Ben Zvi, w towarzystwie dr. hab. prof. UR Elżbiety Rączy i dr. hab. prof. UR Wacława Wierzbieńca.

Marta Lasota

ORCID 0000-0002-1064-36-38

DOI: $10.30657 /$ pha.32.2020.24

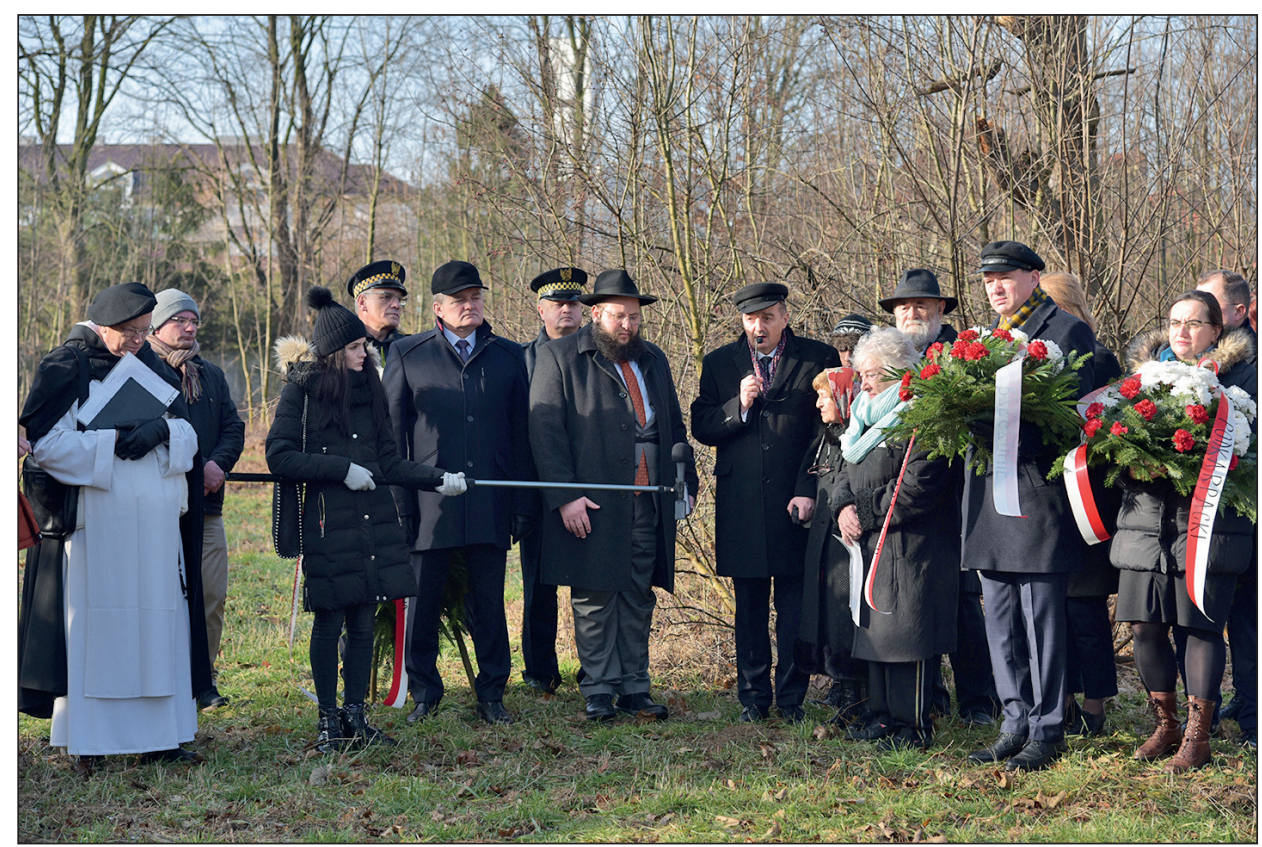

XII Obchody Międzynarodowego Dnia Pamięci o Ofiarach Holokaustu na Podkarpaciu. Modlitwa na cmentarzu żydowskim przy ul. Dołowej w Rzeszowie. Fot. Michał Święcicki, Uniwersytet Rzeszowski. 


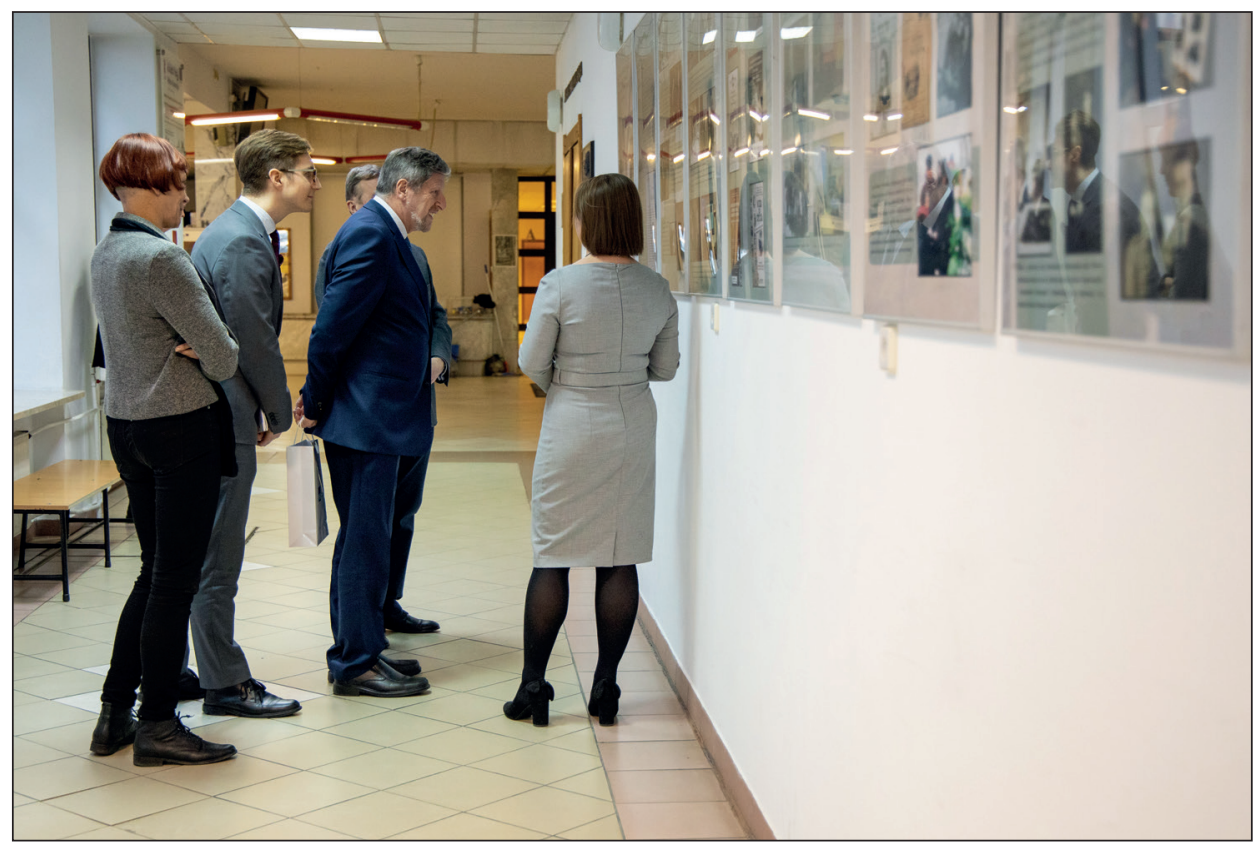

Wizyta Ambasadora Izraela Aleksandra Ben Zvi w Uniwersytecie Rzeszowskim.

Na zdjęciu od lewej: dr hab. prof UR Elżbieta Rączy, Ambasador Izraela Aleksander Ben Zvi, dr hab. prof. UR Wacław Wierzbieniec, Marta Lasota. Fot. Michał Święcicki, Uniwersytet Rzeszowski.

(Muzeum Uniwersytetu Rzeszowskiego) e-mail: malasota@ur.edu.pl 